\title{
Is Speaking Fluency Strand Necessary for the College Students to Develop in the EFL Class?
}

\author{
Yingjie I. J. Yang \\ University of Southern Queensland, Australia
}

\begin{abstract}
This article aims to explore how the EFL teachers and students treat the development of speaking fluency in the EFL class in terms of the teachers' willingness of promoting speaking fluency for their students and the students' demand and preference of the speaking fluency in the EFL class in China. This study also attempts to identify whether there is a dynamic between these two variables. However, the participants in this study including 40 EFL students with a female dominated demography and 10 domestic EFL teachers were randomly convened from a college. Two sets of questionnaire for these EFL teachers and students are a way to observe the result, since the demand of fluency development is a motivational factor for the EFL learners to practice it, while the teachers' willingness of implementation is an effective variable to promote it. Thus, a ttest is applied to precede this outcome and the results indicated that the teachers' willingness of developing speaking fluency for their students is not sufficient. Their students consequently are not familiar with the way of practicing the speaking fluency. Though these EFL students demand a fluent communicative competence in conversations, there is a lack of time, activity, effort and relevant principle of guiding in the current EFL class. The conclusion of this article is that speaking fluency strand is necessary to the college students and therefore further researches should draw attention on its development in the EFL class in China.
\end{abstract}

Index Terms - fluency, speaking fluency, fluency development, preference of speaking fluency, college EFL students, EFL teaching in China

\section{INTRODUCTION}

In the past few decades, there was a gradual but significant change of the language policy in China. Students in high school were not required to learn one elective foreign language. Instead, English was the compulsory subject. In 2001, the Chinese Ministry of Education announced and implemented a compulsory language policy: EFL teaching from the grade 3 in primary schools towards to the tertiary institutions. In addition, the Chinese and English bilingual education was encouraged in the tertiary institutions with $5 \%$ to $10 \%$ of the total courses. This policy did attempt to promote the status of English in this country. Nonetheless, it did not concern the methodology and curriculum more specifically in the EFL context. English language teaching varies from institutions and differs in methodologies across China. Though, there are two common phenomena in summary: EFL is grammar-translation learning and examination-driven teaching. The grammar-translation method is a traditional approach to analyze the grammar structures and rules of a language and students apply these rules to translate their first language into the target language. Richards and Rodgers (2001) pointed out it focuses on developing the reading and writing competences with little attention on the speaking or listening skills, because the purpose of grammar-translation method is to develop the language learners' reading ability. On the other hand, examination-driven learning limits the communicative language learning as students have to process a lot of paper work in order to pass the exams. These two constraints limit the development of communicative language teaching.

On the basis of current situation, the grammar-translation method is steadily replaced by the communicative language teaching approach, which is not yet dominated in many EFL classes in China. Jin (2006) found most EFL learners learn vocabulary through memorizing and practice their listening and reading skills through the context silently. From the view of communicative language teaching, Nation (2007) suggested that there are four strands in a language course: a) language learning through listening and reading is called meaning-focused input; b) form-focused instruction is focused on language features; c) language learning through speaking and writing refers to meaning-focused output, and d) the fluency development is a fourth strand, which is a retrieval of meaning processing. It clearly mentions the importance of fluency development. Thus, this article attempts to discover how the EFL teachers and students treat the development of speaking fluency in the EFL class. This is identified by questionnaires through the relationship between the teachers' willingness of promoting speaking fluency for their students and the students' demand and preference of the speaking fluency. The main finding in this study is that there is a close link between these two variables through interpreting the results of a t-test. In general, the teachers' initiative of promoting speaking fluency determines the students' efforts on it consequently and the importance of speaking fluency development is neglected to some degrees. Finally, there are some recommendations to raise the attention on the speaking fluency strand for the college students in the EFL Class.

\section{LITERATURE REVIEW}

\section{A. The Definition of Fluency}


The term 'fluency' is widely used in language pedagogy and 'fluent' is regularly appeared in language testing, which seems the meaning of fluency is easily catchable. But, the definition of fluency is various. Hartmann and Stork (1976) pointed out the term 'fluent' means a speaker is able to use the correct structures of a language at normal speed, which means speaking naturally with concentration on the content delivery, rather than focusing on the form or structure of a language. Fillmore (1979) defined four abilities of speaking fluently: a) the ability to talk at length with few pauses; b) be able to produce the sentences coherently, reasoned and semantically; c) have appropriate expressions in a wide range of contexts; d) be creative and imaginative in language use. Furthermore, Richards et al. (1985) defined fluency is the speech close to a native speaker's pausing, rhythm, stress and intonations, and in EFL class, fluency is about the level of communication competence. In addition, Nation (1989) provided three aspects of fluency: the first one is the speed and flow of language production; secondly, the degree of control of the language items i.e. pausing, rhythm, pronunciation and stress; and the way of content interrupting. So far, the definition of fluency is developed into two main categories. One is called the narrow approach (Lennon, 2000) refers to the speaking speed and smoothness of the language delivery. The other is the board approach (Kopenen \& Riggenback, 2000) that considers a wider area including semantic density, appropriateness of expression, the language user's creative ability and some further issues in sociolinguistics. However, the definition of fluency is considered as the narrow approach in this study.

\section{B. The Measure of Speaking Fluency}

Defining the term fluency is neither easy, nor is the measure of fluency. It is necessary to set up the relevant criteria to measure speaking fluency in EFL class. To establish the standards of assessing fluency is a complicate task, because fluency is totally a performance with the listener's impression and feeling. Lennon (1990) argued fluency is not inviting the listener to pay attention on production of speaking, but the listener's attention on speaker's message delivered. This is the reflection of the speaker's oral ability. In this circumstance, therefore, many researches attempted to identify the longitudinal fluency development (Towell, 1987; Lennon, 1990 \& Freed, 1995); the researches to distinguish the fluent and non-fluent language learners (Riggenbach, 1991 \& Ejzenberg, 2000); and Arevart and Nation's (1991) fluency improvement in learning an additional language. Most of these researches analyzed the amount of words articulated per minute and the average pauses between the different syllables when speaking. Wood (2001) summarized the speech rate is a key performance indicator of measuring fluency as speech rate shows the overall fluency of speaking. On the other hand, the phenomena of pause and pause filler are also considered in the presence of filled and non-filled pauses in articulation for the four English learners from China (Riggenbach, 1991) and the changes in the pause time for another four German students (Lennon, 1990). To sum up, both the definition and the measure of speaking fluency illustrate the importance of developing the speaking fluency in the EFL class.

\section{The Importance of Fluency}

The goal of learning an additional language is to use it naturally. Brumfit (1984) treated fluency as natural language use like the native speakers. Speaking fluency is also an important component of communication competence, because the ability of speaking fluently can help the speaker to produce continuous speech without comprehension difficulties for the listener and to maintain the communicative ideas more effectively. Richards et al. (1985) argued that the strand of fluency is a measurement of one's communicative proficiency level. So, no language learner refuses to speak fluently. This implies that speaking fluency is necessary for the EFL learners to develop and improve. On the other hand, the issue of fluency or accuracy development, or, meaning or form focused, is widely debated. The best way is to merge them into different sequences in learning because both fluency development and accuracy development are important strands. Nation's (2007) four strands successfully classified them into the different sequence of learning and fluency development is the fourth strand to focus on meaning, which is a retrieval process of the known languages and contents. Moreover, Nation (1997) found that the improvement in speaking fluency also improves qualities of grammar accuracy and the degrees of content control. The practice of the speaking fluency is not conflict with the form-focused instruction, but strongly enhances to the accuracy of a language.

\section{Related Empirical Studies}

Nation's (1989) and Arevart and Nation's (1991) studies of fluency task: the 4/3/2 activity (Maurice, 1983) improved the participants' fluency, grammar accuracy and control of content. First of all, studies were conducted by calculating the amount of words articulated per minute and pauses per 100 words for identifying the improvement of speaking fluency. The results indicated there was an increase in the amount of words speaking per minute and a decrease in the pause per 100 words. Secondly, the accuracy in terms of the number of errors made in the three speaking session was dramatically reduced from the first round with 4 minutes to the third round with 2 minutes in the 4/3/2 activity. The third improvement is about the control of content, which showed a reduction to a good abstract content in order to meet the requirement of the time reduction in each round. To conclude, the techniques used in the studies lead a positive outcome for the development of speaking fluency.

Nation (1997) listed several conditions for developing fluency. This is the fundamental understanding for the EFL teachers to implement a fluency activity in class. The EFL students should be familiar with all language items, content and knowledge. Fluency development does not allow involving any unknown elements. It is a meaning-focused activity, which means the speakers are required to receive and process meaning and not to analyze language features. Moreover, 
there should be some encouragement to push the outcome with a time reduction or speeding up the articulation. If any of these conditions is missing, then it will not be a scientific fluency activity. Nation (2007) further claimed that the four strands should be balanced with an equal share of the class time. That means the EFL teachers and students need to spend $25 \%$ of the class time and put $25 \%$ of their efforts on the fluency development.

Based on these theories above, there are some further empirical studies about the development of speaking fluency. Schloff and Yudkin's (1991) sixty second strategy advised the learners with a slow speaking speed to choose a context about 180 words to read it loudly and practice for several times. Then, these learners are encouraged to recite the content in one minute without losing the original meaning. Fluency is directly associated with the speaking speed in this circumstance. Porter and Grant (1992) argued the EFL learners should not be trained by speeding up with sacrificing meaning and thus to make the conversation difficult for their audiences to understand. Later, Schneider (2001) proposed the pair-taping activity to encourage the EFL learners to interact each other in class due to few opportunities of speaking. Bresnihan and Stoops (1996) further suggested talking zone, speaking line and conversation game to face the challenge of the first language use in class. The over use of native language may impact on the quality of the lesson. In summary, all these proposed activities create an opportunity for the EFL learners to practice the speaking fluency in the EFL class.

\section{RESEARCH QUESTIONS}

The literature review above provides a board picture on the topic of developing and improving the speaking fluency in EFL class. However, this study lists two questions and seeks relevant answers through two sets of questionnaire.

Stated questions:

1. How the EFL teachers and students treat the development of speaking fluency in the EFL class?

2. Is there any relationship between the EFL teachers' willingness of promoting the speaking fluency for their students and the EFL students' preference of the speaking fluency in the EFL class in China?

\section{METHOD}

\section{A. Participants}

This study was designed to identify how the EFL teachers and students treat the development of speaking fluency in the EFL class from a selected college in China. Hence, 40 students are randomly selected in this college. Their major is various, but English is a compulsory subject for all the participants. The demography is a female dominated situation since there are 35 females students in this sample. Another 10 domestic EFL teachers with 6 females and 4 males are convened randomly from this college too. These selected teachers are all middle aged EFL specialists with more than ten years EFL teaching experiences at a college level. About their English proficiency, 5 of them are at the intermediate level, 3 teachers consider their English is close to upper intermediate level and the rest 2 rate their English proficiency at an advanced stage and lower intermediate level. The reason to choose the domestic EFL teachers only is that not all colleges in China have foreign or native EFL teachers. The reliability and valid will be decreased, if asking the overseas EFL teachers to observe. A total number of 50 participants involved in this study as a sample.

\section{B. Instruments}

There are two questionnaires and a five-point scale judgment is applied in this study. The first one is to investigate the teachers' willingness of promoting the speaking fluency for their students and the students' demand and preference of the speaking fluency in the EFL class is in the second questionnaire. A reminder that these two questionnaires ignore the demographical distribution of the participants in the survey, which means the result is applicable for both males and females in this college. These two lists of questionnaires are derived from the theories of fluency development in the literature review above. The items for the teachers' willingness of implementing speaking fluency are closely related to the students' preference of fluency development, which means in this circumstance the questions for the teachers are similar to these questions to the students. For instance, question 1 in the survey for the teachers is - "As a teacher, I inform all my students' that fluency is a necessary strand in language learning (1-disagreed and 5-totally agreed)"; by contrast, for the students is - "I consider the speaking fluency is a necessary strand in language learning (1-Not preferred at all and 5-Preferred very much)". Therefore, such patterns ensure both parties can understand the questions clearly and answer the questions relatively. In order to further increase the reliability and validity for this research, a Chinese version is translated from the English version. Both versions were approved by an expert in this field.

\section{Data Collection}

Before doing this survey, there was a demonstration of this instrument with other teachers and students. It is very important to inform all the participants to provide an authentic score on each question. No discussion about the answers among the participants. They must try all questions in the questionnaires form. It is possible to have an interview with the teachers and students in the demonstration in order to find out the weakness in the questionnaire setting, to consider adding some further questions and to ensure the relevance of the Chinese and English versions. Such demonstration will help the data collection and analysis in a reliable and valid condition. When conducting the formal survey, to convene 
all 50 participants together, to inform them with the purpose of the study, and to provide an instruction of answering the questions in the intended survey, these are the three steps to collect data.

\section{Data Analysis}

The SPSS program was used for the data analysis in this study. The descriptive statistics is to analyze the first stated question how the EFL teachers and students treat the development of speaking fluency in the EFL class. There are two related parts: the teachers' willingness to promote the speaking fluency for their students and the students' demand and preference of the speaking fluency. The evaluating criteria for the interpretation of the mean value of two variables are in table 1 below.

TABLE 1:

CRITERIA FOR THE INTERPRETATION OF THE MEAN VALUE FOR THE TEACHERS' WILLINGNESS OF PROMOTING THE SPEAKING FLUENCY FOR THEIR STUDENTS AND THE STUDENTS' PREFERENCE AND DEMAND OF THE SPEAKING FLUENCY IN THE EFL CLASS OF THE SAMPLE WITH 50 PARTICIPANTS

\begin{tabular}{l|l|l|l}
\hline Mean Value & Level of Teachers' Willingness (Agreement) & Level of Students' Demand (Preference) & \\
\hline $4.21-5.00$ & Strongly agree & Preferred very much & \\
\hline $3.41-4.20$ & Agree & Preferred to some degree & \\
\hline $2.61-3.40$ & Uncertain & Uncertain & \\
\hline $1.81-2.60$ & Disagree & Rarely prefer & \\
\hline $0.00-1.80$ & Strongly disagree & Not preferred at all & \\
\hline
\end{tabular}

For the stated question 2, a t-test is used to identify whether there is any dynamic relationship between the teachers' willingness of promoting the speaking fluency for their students and the students' preference of the speaking fluency.

E. Results

TABLE 2:

THE TEACHERS' WILLINGNESS TO PROMOTE THE FLUENCY OF SPEAKING FOR THEIR STUDENTS IN THE EFL CLASS OF SAMPLE WITH 10 PARTICIPANTS

\begin{tabular}{|c|c|c|c|}
\hline \# & Questions & Mean Value & Level of Agreement \\
\hline 1 & As a teacher, I inform all my students' that fluency is a necessary strand in language learning & 4.40 & Strongly agree \\
\hline 2 & I indeed spend $25 \%$ of time on fluency development in class & 1.60 & Strongly disagree \\
\hline 3 & I organize different activities for my students to practice speaking fluency regularly & 3.60 & Agree \\
\hline 4 & I certainly understand and apply the conditions of running a speaking fluency activity in class & 3.70 & Agree \\
\hline 5 & I clearly provide instructions on how to practice the speaking fluency in class & 2.90 & Uncertain \\
\hline 6 & I always ask the students to practice the known language and content for their speaking skill & 3.20 & Uncertain \\
\hline 7 & I attempt to create more speaking opportunities for my students to use the known language items & 4.30 & Strongly agree \\
\hline 8 & I am keen to encourage the students to focus on meaning when practice speaking fluency & 1.60 & Strongly disagree \\
\hline 9 & I push the EFL students to speak faster in fluency development & 1.70 & Strongly disagree \\
\hline 10 & I motivate the students to repeat the same context until they easily control the context & 3.30 & Uncertain \\
\hline \multirow[t]{2}{*}{11} & I am confident with my students' communicative competence to maintain the real conversations & 3.30 & Uncertain \\
\hline & Average & 3.05 & Uncertain \\
\hline
\end{tabular}

Table 2 shows two items (Question 1 \& 7) are strongly agreed by the 10 teachers. Question 1 has the highest average mean value with 4.40 due to the majority of the teachers agree with the statement of fluency development is a necessary strand in language learning; two items (Question $3 \& 4$ ) are agreed by them who understand and apply the conditions for running a fluency activity and organize different activities for fluency development in class; four uncertain items (Question 5, 6, 10 and 11); and the rest three items (Question 2, 8 and 9) are strongly disagreed.

TABLE 3

THE STUDENTS' DEMAND AND PREFERENCE OF THE SPEAKING FLUENCY IN THE EFL CLASS OF THE SAMPLE WITH 40 PARTICIPANTS

\begin{tabular}{l|l|l|l}
\hline$\#$ & Questions & Mean Value & Level of Agreement \\
\hline 1 & I consider the speaking fluency is a necessary strand in language learning & 4.45 & Preferred very much \\
\hline 2 & I do put 25\% of time and effort on fluency development in class & 1.70 & Not preferred at all \\
\hline 3 & I would like to practice my speaking fluency regularly through different activities & 3.88 & Preferred to some degree \\
\hline 4 & I certainly require the conditions for participating in a fluency activity & 3.63 & Preferred to some degree \\
\hline 5 & I can clearly follow the instructions on how to practice the speaking fluency & 2.98 & Uncertain \\
\hline 6 & I attempt to practice the known language and content for the speaking skill & 2.95 & Uncertain \\
\hline 7 & I try my best to be involved in any opportunity to use and practice my known language items & 3.28 & Uncertain \\
\hline 8 & I put effort on focusing and processing meanings when I practice speaking fluency & 1.95 & Rarely prefer \\
\hline 9 & I push myself to increase my speaking with a faster speed in fluency development & 2.38 & Rarely prefer \\
\hline 10 & I repeat the same context until I can easily control the context & 2.95 & Uncertain \\
\hline 11 & I really need a good level of communicative competence to maintain the real conversations & 3.18 \\
\hline & Average & 3.03 & Uncertain \\
\hline
\end{tabular}

Table 3 shows only one item is strongly agreed by all the participating students. Question 1 has the highest average mean value with 4.45 since 36 out of the students prefer or prefer very much to the statement of fluency development is a necessary strand in language learning; two items (Question $3 \& 4$ ) are preferred to some degrees that the students can understand the conditions for practicing a fluency activity and join in different activities for fluency development in 
class; the next five uncertain items (Question 5,6,7,10 and 11) and the rest 3 items: Question 2 is not preferred at all Question $8 \& 9$ are rarely preferred. The average rate of this questionnaire is 3.03 with an uncertain criterion.

TABLE 4:

DIFFERENCES BETWEEN THE TEACHERS’ WILLINGNESS OF PROMOTING THE SPEAKING FLUENCY FOR THEIR STUDENTS AND THE STUDENTS' DEMAND AND PREFERENCE OF THE SPEAKING FLUENCY IN THE EFL CLASS (PAIRED T-TEST WITH TWO TAILED)

\begin{tabular}{|c|c|c|c|c|c|c|}
\hline & \multicolumn{2}{|c|}{ Teachers $(\mathrm{n}=10)$} & \multicolumn{2}{|c|}{ Students $(n=40)$} & \multirow{2}{*}{ T Calculated } & \multirow[b]{2}{*}{ Sig. (2-tailed) } \\
\hline & Mean & SD & Mean & SD & & \\
\hline 1 & 4.40 & 0.70 & 4.45 & 0.75 & -0.1993 & 0.84 \\
\hline 2 & 1.60 & 0.84 & 1.70 & 0.76 & -0.3421 & 0.73 \\
\hline 3 & 3.60 & 0.84 & 3.88 & 0.72 & -0.9479 & 0.35 \\
\hline 4 & 3.70 & 0.67 & 3.63 & 0.74 & 0.3081 & 0.76 \\
\hline 5 & 2.90 & 0.57 & 2.98 & 0.86 & -0.3328 & 0.74 \\
\hline 6 & 3.20 & 0.79 & 2.95 & 0.71 & 0.9130 & 0.37 \\
\hline 7 & 4.30 & 0.67 & 3.28 & 0.78 & $4.1527 * *$ & 0.00 \\
\hline 8 & 1.60 & 0.70 & 1.95 & 0.68 & -1.4246 & 0.16 \\
\hline 9 & 1.70 & 0.82 & 2.38 & 0.74 & $-2.3647 *$ & 0.02 \\
\hline 10 & 3.30 & 0.48 & 2.95 & 0.78 & 1.7802 & 0.08 \\
\hline 11 & 3.30 & 0.95 & 3.18 & 0.68 & 0.3926 & 0.70 \\
\hline Average & 3.05 & 0.73 & 3.03 & 0.75 & 0.1050 & 0.92 \\
\hline
\end{tabular}

Table 4 shows the paired t-test results: only 1 item (Question 7) among the total 11 questions was identified between the mean value of the teachers' willingness of developing speaking fluency and the students' preference of practicing speaking fluency with a significant difference at $1 \%(\mathrm{p}<0.01)$ level. The rest 10 items were perfectly related with these two variables between the teachers and students. The statistical figures of item 1, 2, 3, 5, 8 and 9 illustrated that the students' preference is generally greater than the teachers' willingness for the development of speaking fluency. It is necessary to point out item 8 - the student's question: I put effort on focusing and processing meanings when I practice speaking fluency, which is much greater than the teacher's question: I push the EFL students to speak faster in fluency development. However, item 9 - the student's question: I push myself to increase my speaking with a faster speed in fluency development, is even close to a significant difference (Sig. $=0.02,2$ tailed) to the teacher's question: I motivate the students to repeat the same context until they control the context easily. Thus, item 9 will be a significant difference, if the degree of freedom is at $5 \%(\mathrm{p}<0.05)$ level.

On the other hand, the rest four items 4, 6, 10 and 11 resulted that the teachers' willingness and efforts on developing fluency is greater than the students' preference in the EFL class. These two variables also closely related. For example, item 6 - I always ask the students to practice the known language and content for their speaking skill, and item 10 - the EFL teachers encouraging the repetition of the same context until the language learners are able to control the context easily, which are closely followed by the students. To sum up, the mean value for teachers' willingness is 3.05 and 3.03 is for students' preference. There is a close matching between the teachers' willingness of promoting speaking fluency and the students' preference in this study. Nevertheless, the final outcome is still located in the uncertainty level.

\section{FINDINGS AND IMPLICATIONS}

First of all, the teachers' willingness and students' preference of developing the speaking fluency are internal related in this research, but the overall outcome is with an uncertain attention on the fluency development. This provides a very strong reason to balance four strands in a language program immediately. To analyze these findings more specifically, the strand of speaking fluency is totally ignored by these participated teachers and students, who evaluated a mean value of 1.6 and 1.7 on item 2 - the weight of fluency development in class in the questionnaires. This implies they did not pay attention on fluency development at all. Nonetheless, they have several reasons and one common explanation is that the EFL teachers are usually making progress to focus on teaching new materials in class. They consider homework is a kind of revision and students believe learning new things are worthwhile, whereas the retrieval of the known content is a waste of time. Through an interview after this research, the participants including both the teachers and students think a quarter of the class time on fluency development is too much. Nation (2007) argued that fluency strand is necessary for any proficiency level when learning a foreign language. The purpose for learning is best to use what already known. So, the EFL learners are strongly required to put their efforts on fluency development. It is true that the speaking is the most important skill in learning a foreign language (Ur, 1996). A large demand of the speaking skill creates many opportunity to improve the speaking fluency. Thanesh (2013) explores that there is a shift towards focusing on speaking fluency development in India now. Consequently, the attention should be paid on meaning-focused output and fluency development strands for improving the communicative competence.

On the other hand, though the mean values 3.70 (teachers) and 3.63 (students) with an agreed and preferred criterion on item 4 - the understanding of the condition of speaking fluency, however, the understanding of this concept is not sufficient. Item 6 refers to the known language and content; item 7 is the input and output opportunities; the feature of meaning-focused is related to item 8; item 9 is about speeding up in speaking and item 10 is considered as a repetition strategy. These are all conditions and features for developing speaking fluency. Indeed, they were poorly answered by 
either the teachers or the students, which imply item 4 is not reliable and valid. It is necessary to review the conditions and features for these participants. To perform a fluency task, the conditions and features are mandatory to consider first, otherwise the practice of fluency is not standardized or not effective. Thus, if there is an insufficient understanding of the rationale for fluency development; if there is a lack of opportunities for the repetition of the known languages and contents; if speaking is not pushed by speed; it will be difficult to achieve the goal of developing the speaking fluency, which not only has a feature of meaning-focused processing and retrieval, but also contributes to the form-focused instruction in terms of the increase of grammar accuracy and the control of content (Nation, 1989).

Next, the exception of the internal relationship in this study is item 7 - the teachers' effort on creating more speaking opportunities for their students to use the known language items is great, instead, the students response a low preference. No matter how the teachers encourage their students to participate in class, there is always a low response in a grammar translation learning environment. This raises two considerations: the adoption of the communicative language teaching in the EFL class in China is necessary and the other is about motivation is a tool to maintain the learning. Item 7 is a typical situation that the teachers know its importance, but the students do not engage very well. This is a gap between knowing and doing. Therefore, motivation is a strategy to fill this gap. The EFL teachers need to reflect motivational strategies with their learners' achievements together. Motivation is a way to enhance the speaking fluency development, because the teacher's motivation strategies can attract the students' interest of learning and thus the EFL learners gain motivation from their teachers to maintain the EFL learning more effectively (Dörnyei, 1994). In summary, motivation supports to make achievements in EFL learning. This is an analysis why students' engagement is very weak in item 7. Furthermore, Dörnyei (2003) pointed out the motivation also effects on the individual's progress to evaluate what was achieved; how it was achieved and to plan for the next step of learning. One responsibility for the EFL teachers is to use the motivational strategies to achieve what learners expected as well as the objectives of the EFL course. Students will therefore continue to put their efforts on the next level of learning.

Brown (2007) stated motivation is yet an affective variable to be considered in the language teaching and learning. To compare with learning new things, motivation will be more powerful. The motivation strategy increases the quality in learning and enhances the using of language and content repetitively outside the class. The EFL learners should: a) be familiar with the language items and content; b) repeat them until with a fast speaking speed, few unnecessary pauses, and without losing the original meanings; c) understand the practice and learning with motivation; d) easily control and restructure the content; e) maintain a conversation with the similar languages and contents in real communication. In class, the EFL learners can choose the topic that is actually happened in their life (Brown \& Nation, 1997). There are many topics and activities for developing the speaking fluency, for example, to describe a place one visited before can be talked through the 4/3/2 activity (Maurice, 1983). Students can cultivate their communicative competence because the topic and content practiced in class can be applied in real life again, but at a more fluent level.

On the whole, Brown (2002) stated that English language teaching now requires diagnosis, treatment and assessment. Diagnosis is the first step to identify learners' needs, necessities and wants (Nation \& Macalister, 2010). To diagnose what the EFL learners' target knowledge that is expected to learn. In order to achieve the goal of the course, to explore what the necessity of knowledge they should have; and what is the lack parts. It is obvious that the speaking fluency is lacked in this study. To treat such issue, these teachers need to understand the fluency strand; to believe that speaking fluency is a trainable skill (Arevart \& Nation, 1991); to increase the portion of fluency development in class; and to adjust and improve the curriculum of the course if they can. Findings in this study indicate that the teachers should have initiatives to do so. Finally, the assessment is a check point for the treatment and improvement. After processing of the assessment, the EFL teachers still have time to interview the students. The relevant and valuable feedbacks from the interview should be considered for the next improvement session.

\section{CONCLUSION}

This study aims to explore the necessity for speaking fluency development in college institutions in China. In the light of the treatment of speaking fluency in the EFL class, a sample of 10 teachers and 40 students were participated in the survey. The researches indicated that there is a close relationship between the teachers' willingness and students' preference of implementing and developing the speaking fluency. However, the general status of speaking fluency is on a weak attention. In a communicative language teaching environment, the teachers should balance the four strands and shift from a heavy portion of form-focused instruction to meaning-focused processing. In this sense, this study holds a point of view that developing speaking fluency is an important strand in language learning.

There was a little differences between the two variables that the teachers' willingness and students' preference of implementing the development of speaking fluency. However, this study is limited in the area of college EFL courses with a female dominated demography. There might be a significance and uniqueness in other different academic levels or other demographics groups. It will be very interesting if further researches on the opposite demography with a male dominated population. In conclusion, this research provides a picture on the situation of the development of speaking fluency for the college students, it is important to know the way of promoting speaking fluency. It is also a challenging task. Therefore, further research should draw attention on how to improve the speaking fluency. 


\section{REFERENCES}

[1] Arevart, S. \& Nation, I.S.P. (1991). Fluency improvement in a second language. RELC Journal 22.1, 84-94.

[2] Bresnihan, B. \& Stoops, B. (1996). Three ways that work! Oral fluency practice in the EFL classroom. English Teaching Forum 34.3, 30.

[3] Brown, H. D. (2002). English language teaching in the "post-method" era: Toward better diagnosis, treatment and assessment. In J. C. Richards and W. A. Renandya (eds.), Methodology in language teaching: An anthology of current practice. Cambridge: Cambridge University Press, 9-18.

[4] Brown, H.D. (2007). Principles of language learning and teaching (5th edn.). New York: Pearson Longman.

[5] Brown, S. \& Nation, I.S.P. (1997). Teaching speaking: suggestions for the classroom. The Language Teacher 21.1, 11-18.

[6] Brumfit, C. (1984). Communicative methodology in language teaching: The roles of fluency and accuracy. Cambridge: Cambridge University Press.

[7] Dörnyei, Z. (1994). Motivation and motivating in the foreign language classroom. The Modern Language Journal 78.3, 273284.

[8] Dörnyei, Z. (2003). Attitudes, orientations, and motivations in language learning: Advances in theory, research and applications. Language Learning 53.1, 3-32.

[9] Ejzenberg, R. (2000). The juggling act of oral fluency: A psycho-sociolinguistic metaphor. In H. Riggenbach (eds.), Perspectives on fluency. Michigan: The University of Michigan Press, 287-314.

[10] Fillmore, C. J. (1979). On fluency. In D. Kempler \& W. S. Y. Wang (eds.), Individual differences in language ability and language behavior. New York: Academic Press, 85-102.

[11] Freed, B. (1995). What makes us think that students who study abroad become fluent? In B. Freed (eds.), Second language acquisition in a study abroad context. Amsterdam: John Benjamins, 123-148.

[12] Hartmann, R. R. K. \& Stork, F. C. (1976). Dictionary of language and linguistics. New York: Wiley.

[13] Jin, Y. (2006). The improvement of the test validity and its backwash effects. Foreign Language World 6, 65-73.

[14] Kopenen, M. \& Riggenbach, H. (2000). Overview: Varying perspectives on fluency. In H. Riggenbach (eds.), Perspectives on fluency. Ann Arbor, MI: The University of Michigan Press, 5-24.

[15] Lennon, P. (1990). Investigating fluency in EFL: A quantitative approach. Language Learning 40, 387-412.

[16] Lennon, P. (2000). The lexical element in spoken second language fluency. In H. Riggenbach (eds.), Perspectives on fluency. Ann Arbor, MI: The University of Michigan Press, 25-42.

[17] Maurice, K. (1983). The fluency workshop. TESOL Newsletter 17.4, 29.

[18] Nation, I.S.P. (1989). Improving speaking fluency. System 17.3, 377-384.

[19] Nation, I.S.P. (1991). Fluency and learning. The English Teacher 20, 1-8.

[20] Nation, I.S.P. (1997). Developing fluency in language use. KIFL Academic Journal 6, 30-35.

[21] Nation, I.S.P. (2007). The four strands. Innovation in Language Learning and Teaching 1.1, 1-12.

[22] Nation, I.S.P. \& Macalister, J. (2010). Language curriculum design. New York, NY: Routledge.

[23] Porter, P. \& Grant, M. (1992). Communicating effectively in English: Oral communication for non-native speakers. Belmont: Wadsworth Publishing Company.

[24] Richards, J. C., Platt, J. \& Weber, H. (1985). Longman dictionary of applied linguistics. London: Longman.

[25] Richards, J.C. \& Rodgers, T. (2001). Language and methods in language teaching. Cambridge: Cambridge University Press.

[26] Riggenbach, H. (1991). Towards an understanding of fluency: A microanalysis of nonnative speaker conversation. Discourse Processes 14, 423-441.

[27] Schloff, L. \& Yudkin, M. (1991). Smart speaking: Sixty-second strategies. New York: Henry Holt and Company.

[28] Schneider, P. (2001). Pair taping: Increasing motivation and achievement with a fluency practice. TESL-EJ 5.2, 1-32.

[29] Thanesh, U. (2013). Testing oral skills: An innovative approach to promote fluency. Language in India 13.3, 381-390.

[30] Towell, R. (1987). Variability and progress in the language development of advanced learners of a foreign language. In R. Ellis (eds.), Second language acquisition in context. Toronto: Prentice Hall, 113-127.

[31] Ur, P. (1996). A course in language teaching: Practice \& theory. Cambridge: Cambridge University Press.

[32] Wood, D. (2001). In search of fluency: What is it and how can we teach it? Canadian Modern Language Review 57.4, 573-589.

Yingjie I. J. Yang graduated from Victoria University of Wellington, New Zealand and after that he started to teach and instruct EFL courses and train EFL teachers in China. His research interests are EFL teaching and learning, listening and speaking skills, fluency development and bilingual education. 